\title{
Quality yarn index using AHP and Fuzzy method
}

\author{
DOI: 10.35530/IT.071.05.1699
}

\section{ABSTRACT - REZUMAT}

\section{Quality yarn index using AHP and Fuzzy method}

The yarn quality depends on many parameters: characteristics parameters, mechanical and physical properties. Making the hypothesis that the quality of the yarn is a multicriteria problem, in this paper, we propose a new method to determine the Quality Yarn Index QYI based on Analytic Hierarchy Process AHP and Fuzzy theory.

A questionnaire was designed for experts of each field (weaving and knitting) to evaluate the relative importance for each property to determine coefficients of the AHP matrix.

Results revealed that matrix coefficients changed with yarn application (weft or warp weaving and knitting)

The QYI can be used in any application, where a rapid decision is needed, to evaluate the global quality of yarn and to make a comparison between different yarn qualities.

Keywords: yarn quality index, mechanical properties, physical properties, Fuzzy AHP

\section{Determinarea indicelui de calitate al firelor folosind metoda AHP Fuzzy}

Calitatea firului depinde de mulți parametri: caracteristici mecanice și fizice. Bazându-ne pe ipoteza conform căreia calitatea firului este o problemă multicriterială, în această lucrare, propunem o nouă metodă de determinare a indicelui de calitate a firului QYI bazat pe Procesul de ierarhie analitică AHP și teoria Fuzzy.

A fost conceput un chestionar pentru experții din fiecare domeniu (țesătorie și tricotaje), pentru a evalua importanța relativă pentru fiecare caracteristică, cu scopul de a determina coeficienții matricei AHP.

Rezultatele au redat modificarea coeficiențiilor matricei odată cu schimbarea domeniului de utilizare al firelor (țesere și tricotare în bătătură sau urzeală).

QYI poate fi utilizat în orice aplicație, acolo unde este necesară o decizie rapidă, pentru a evalua calitatea globală a firelor și pentru a face o comparație între diferiți indici de calitate ai firelor.

Cuvinte-cheie: indice de calitate al firelor, caracteristici mecanice, caracteristici fizice, Fuzzy AHP

\section{INTRODUCTION}

The Textile yarns are used in a wide range of applications: warp and weft weaving, knitting, garment industry. The Quality of yarn directly affects the yield of production and the quality of the final product. For a long period, yarn quality was qualified through its strength [1-6].

Quality of yarn is a multi-criteria problem that needs the simultaneous satisfaction of a lot of properties (mechanical, physical properties ...)

Yunus [7] proposed a yarn quality index considering yarn strength, elongation, and uniformity. This index was used in some research papers to optimise the quality of waste yarn [8-9].

Souied [10] proposed a method based on Soft Computing Technique to predict the Global Yarn quality from that of fiber.

Recently, Wannssi proposed to use AHP method to optimise the global quality of yarns with different waste ratio taking into account the fiber price [11]. In the textile industry, it is very useful to use a Global Quality Index, especially when purchasing in order to make a rapid comparison between yarn quality from different suppliers and when comparison of a new yarn quality to standard is necessary. This Index should be determined according to customer satisfaction criteria that varies from one final product application to another.

In this paper, we propose a new method to determine the Quality Yarn Index QYI based on Analytic Hierarchy Process AHP and Fuzzy theory.

A questionnaire was designed for experts of each field (weaving and knitting) to evaluate the relative importance for each property to determine coefficients of the AHP matrix.

\section{Materials and methods}

\section{Yarn Quality Index}

According to Yunus [7], a Yarn quality Index can be expressed by the following formula:

$$
Y Q I=\frac{Y S t \times Y E I}{Y C V}
$$

where YSt is Yarn Strength, YEI - Yarn Elongation, YCv - Yarn Uneveness.

This index has many advantages, it is simple and takes into account most of the important properties of yarn but also has disadvantages: 
- Some other important properties of the yarn are missing (Neps, Hairiness, Elasticity...);

- The index considers that all the properties have the same importance (weight $=1$ ).

Taking into account, these remarks, we propose in our study a new empirical index of yarn quality. This index can be expressed by the following formula:

$$
\begin{gathered}
Y Q I=\sum_{i=1}^{n} W G i \text { GPi } \\
\sum_{i=1}^{n} W G i=1
\end{gathered}
$$

where $\mathrm{GPi}$ is Global property $i$ of the yarn (Dynamometric property, Uneveness, Hairiness...), WG $i$ - Weight of the global property $I, n-$ Number of yarn properties to take into account.

Each global property GPi can be expressed as a function of Relative Properties of the yarn RPj (for example the Global property of the yarn: dynamometric properties, can be expressed by the relative properties: tenacity, breaking elongation and elasticity).

$$
\begin{gathered}
G P i=\sum_{j=1}^{m i} W R j i \text { RPji } \\
\sum_{j=1}^{m i} W R j i=1
\end{gathered}
$$

where $R P j i$ is Relative property $j$ of the Global property $i$ of the yarn, $W R j i$ - Weight of the relative property $j$ to the global property $i$ of the yarn, $m i-$ Number of relative properties related to the global property I of the yarn.

The objective of our study is to propose an appropriate approach based on AHP and Fuzzy methods to determine respectively the weights of Global properties of the yarn WGi and the weights of relative properties WRji based on customer satisfaction and final application of the yarn (weaving, knitting...).

\section{Fuzzy AHP process}

AHP is a common multi-criteria decision making method. It is developed by Saaty [12] to assist in solving complex decision problems by capturing both subjective and objective evaluation measures. The fuzzy AHP method includes the uncertain (imprecise) judgment of experts by utilizing linguistic variables (table 1). Recently many researchers have used this approach in various areas [13-15].

In fuzzy AHP, $\check{A}=\left(\check{a}_{i j}\right)$ is a fuzzy pairwise comparison judgment matrix, with $\check{a}_{i j}=\left(I_{i j}, m_{i j}, u_{i j}\right)$ the pairwise com-

\begin{tabular}{|c|c|c|}
\hline \multicolumn{3}{|c|}{ FUZZY AHP METHOD } \\
\hline $\begin{array}{c}\text { Preference of pairwise } \\
\text { comparisons }\end{array}$ & $\begin{array}{c}\text { Fuzzy } \\
\text { scale }\end{array}$ & $\begin{array}{c}\text { Fuzzy } \\
\text { reciprocal } \\
\text { scale }\end{array}$ \\
\hline Just equal & $(1,1,1)$ & $(1,1,1)$ \\
\hline Very weakly more important & $(1 / 2,1,3 / 2)$ & $(2 / 3,1,2)$ \\
\hline Weakly more important & $(1,3 / 2,2)$ & $(1 / 2,2 / 3,1)$ \\
\hline Moderately more important & $(3 / 2,2,5 / 2)$ & $(2 / 5,1 / 2,2 / 3)$ \\
\hline Strongly more important & $(2,5 / 2,3)$ & $(1 / 3,2 / 5,1 / 2)$ \\
\hline Absolutely more important & $(5 / 2,3,7 / 2)$ & $(2 / 7,1 / 3,2 / 5)$ \\
\hline
\end{tabular}

parisons between the elements $i$ and $j$ and a triangular fuzzy number where $I_{i j}$ and $u_{i j}$ are the lower and upper limits respectively and $m_{i j}$ the modal value and $l_{i j} \leq m_{i j} \leq u_{i j}$. If $I_{i j}=m_{i j}=u_{i j}$ it is considered a non-fuzzy number by convention. The membership function $\mu_{x}$ is defined as:

$$
\mu(x)= \begin{cases}\left\{\frac{x}{m-l}-\frac{I}{m-I},\right. & x \in[I, m] \\ \left\{\frac{x}{m-u}-\frac{1}{m-u},\right. & x \in[m, u] \\ 0, & \text { oterwise }\end{cases}
$$

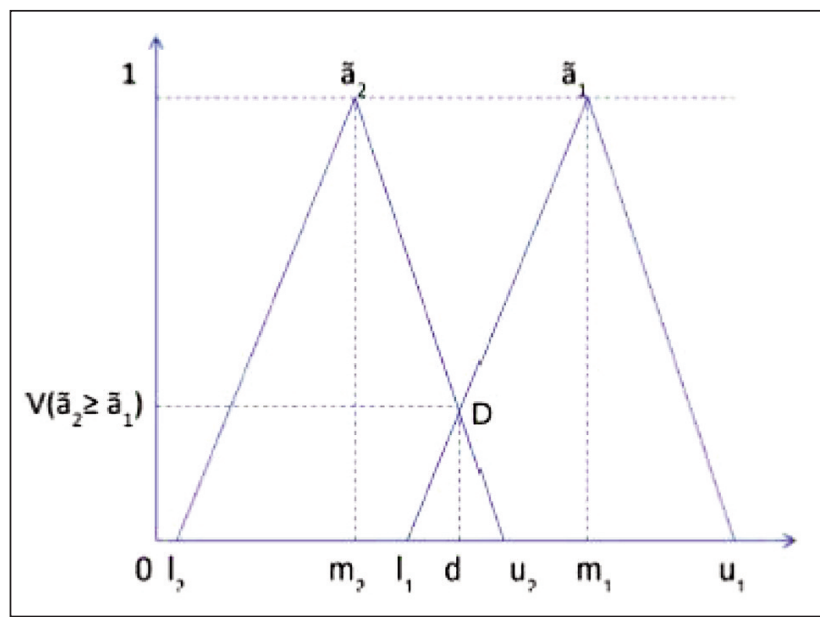

Fig. 1. Intersection between $\widetilde{\mathrm{a}}_{1}$ and $\widetilde{\mathrm{a}}_{2}$

The procedure for applying fuzzy AHP is as follows $[16,17]$ :

- Define the hierarchical structure of the decision problem.

- Make pairwise comparisons of criteria at the same level of hierarchy using fuzzy numbers to construct the matrix $\check{A}$.

- The fuzzy synthetic extent value (Si) with respect to the $i^{\text {th }}$ criterion is defined as:

$$
\widetilde{S_{i}}=\sum^{m} \widetilde{a_{g_{i}}^{j}} \times\left[\sum^{n} \sum^{m} \widetilde{a}_{g_{i}}^{j}\right]^{-1}
$$

where $g_{i}$ are the goals of the hierarchy and $\widetilde{a}_{g_{i}}^{j}$ is a triangular fuzzy number of the decision matrix $\check{A}$ with $n$ objects and $m$ goals.

- The degree of possibility is calculated by:

$$
\begin{gathered}
V\left(\tilde{a}_{2} \geq \tilde{a}_{1}\right)=\operatorname{hgt}\left(\tilde{a}_{1} \cap \tilde{a}_{2}\right)=\mu_{\tilde{a}_{2}}(d)= \\
= \begin{cases}1, & \text { if } m_{2} \geq m_{1} \\
0, & \text { if } I_{1} \geq u_{2} \\
\frac{l_{1}-u_{2}}{\left(m_{2}-u_{2}\right)-\left(m_{1}-I_{1}\right)} & \text { otherwise }\end{cases}
\end{gathered}
$$

Where $d$ is the ordinate of the highest intersection point $D$ between $\mu_{\tilde{a}_{1}}$ and $\mu_{\tilde{a}_{2}}$.

- The minimum degree of possibilit of $V\left(\tilde{S}_{j} \geq \tilde{S}_{j}\right)$ for $i, j=1,2, \ldots, n$ is calculated:

$V\left(\widetilde{S}_{j} \geq \widetilde{S}_{1}, \widetilde{S}_{2}, \ldots, \widetilde{S}_{n}\right)=V\left(\widetilde{S}_{j} \geq \widetilde{S}_{1}\right)$ and $V\left(\widetilde{S}_{j} \geq \widetilde{S}_{2}\right)$ and $\ldots V\left(\tilde{S}_{j} \geq \tilde{S}_{n}\right)=\min V\left(\tilde{S}_{j} \geq \tilde{S}_{i}\right), i=1,2, \ldots, n$ 
- If $d^{\prime}\left(A_{i}\right)=\min V\left(\widetilde{S}_{j} \geq \tilde{S}_{i}\right)$ for $j=1,2, \ldots, n$ and $j \neq i$.

The weight vector is:

$$
W=\left(d^{\prime}\left(A_{1}\right), d^{\prime}\left(A_{2}\right), \ldots, d^{\prime}\left(A_{n}\right)^{T}\right.
$$

- Via normalization, the normalized weight vectors are given as follow:

$$
W=\left(d\left(A_{1}\right), d\left(A_{2}\right), \ldots, d\left(A_{n}\right)^{T}\right.
$$

- Notice that $A$ is considered consistent if $A^{\prime} \times W=$ $=n \times W$.

- The consistency ratio $(C R)$ is calculated from as:

$$
\begin{gathered}
C R=\frac{C l}{R C l}=\frac{\text { Consistency Index }}{\text { Random Consistency of } A} \\
C l=\frac{\lambda_{\max }-n}{n-1}
\end{gathered}
$$

where $\lambda_{\max }$ is equal to the sum of the elements of the column vector $A ́ W$.

$\mathrm{RCl}$ is generated by a random matrix of similar dimension. Random consistency index (RCl) for the matrix of the order of 1 to 15 as shown in table 2 .

If $C R$ is less than 0.1 , the judgments given in a comparison matrix are adequa.

\begin{tabular}{|c|c|c|c|c|c|c|c|c|c|}
\hline \multicolumn{10}{|c|}{ RANDOM CONSISTENCY INDEX [12] } \\
\hline $\mathrm{N}$ & 1,2 & 3 & 4 & 5 & 6 & 7 & 8 & 9 & 10 \\
\hline $\mathrm{RCl}$ & 0.00 & 0.58 & 0.90 & 1.12 & 1.24 & 1.32 & 1.41 & 1.45 & 1.49 \\
\hline
\end{tabular}

\section{RESULTS AND DISCUSSION}

Contrary to knitting fabric technology where only one set of yarns are used, in woven fabric manufacturing two types of yarns are needed: warp and weft yarns. To ensure the quality of each kind of fabric, different yarn properties are required.

Most of the spinners work continuously to predict and translate a set of requirements for spinning guidelines that satisfy weaver and knitters standards.

\begin{tabular}{|c|c|c|c|}
\hline $\begin{array}{c}\text { Dynamometric } \\
\text { properties }\end{array}$ & $\begin{array}{c}\text { Neps \& } \\
\text { hairiness }\end{array}$ & $\begin{array}{c}\text { Eveness } \\
\text { properties }\end{array}$ & $\begin{array}{c}\text { Structural } \\
\text { characteristics }\end{array}$ \\
\hline Tenacity & Neps & $\mathrm{CV}(\%)$ & Linear Density \\
\hline $\begin{array}{c}\text { Breaking } \\
\text { elongation }\end{array}$ & Hairiness & Thin places & Twist \\
\hline Elasticity & & Thick places & \\
\hline
\end{tabular}

Fig. 2. Hierarchical Structure of Yarn Properties

For this purpose, a fuzzy AHP model has been developed to assess the yarn importance for the three yarn types: warp, weft, and knitting.

Firstly, the weight of each yarn properties will be determined and then for each application, a Global Yarn Quality index will be defined.

Based on literature review then spinners, weavers and knitters managers interviewing, four main criteria were defined for the most important yarn properties required for weaving (wrap and weft) and knitting technologies: Dynamometric properties, Neps \& Hairiness, Evenness properties, and structural characteristics. Within each main criterion, there are various sub-criteria to which we assign specific descriptors (figure 2).

Two experts provided judgments for each yarn types: warp, weft, and knitting. These experts used for obtaining the fuzzy numbers have over ten years' experience in weaving and knitting fields. Fuzzy numbers have been used to assign weightings to the criteria and sub-criteria. They were asked to evaluate the importance of the criteria and sub-criteria applying the triangular fuzzy scale shown in table 1 . The pairwise comparison matrix for the criteria given by the experts is shown in table 3 .

Upon completing the model analysis, the criterion with the highest weightage was found for each yarn employment: weaving warp, weaving weft and knitting yarn (table 4). It was found that the dynamometric property is the most important criterion throughout.

\begin{tabular}{|c|c|c|c|c|c|c|c|c|c|c|c|c|}
\hline \multicolumn{13}{|c|}{ PAIRWISE COMPARISON MATRIX OF CRITERIA (TWO EXPERTS) } \\
\hline \multirow{2}{*}{ Properties } & \multicolumn{3}{|c|}{$\begin{array}{l}\text { Dynamometric } \\
\text { properties }\end{array}$} & \multicolumn{3}{|c|}{ Neps \& hairiness } & \multicolumn{3}{|c|}{ Evenness properties } & \multicolumn{3}{|c|}{ Structural characteristics } \\
\hline & $\begin{array}{l}\text { Warp } \\
\text { yarn }\end{array}$ & $\begin{array}{l}\text { Weft } \\
\text { yarn }\end{array}$ & $\begin{array}{c}\text { Knitting } \\
\text { yarn }\end{array}$ & $\begin{array}{l}\text { Warp } \\
\text { yarn }\end{array}$ & $\begin{array}{l}\text { Weft } \\
\text { yarn }\end{array}$ & $\begin{array}{c}\text { Knitting } \\
\text { yarn }\end{array}$ & $\begin{array}{l}\text { Warp } \\
\text { yarn }\end{array}$ & $\begin{array}{l}\text { Weft } \\
\text { yarn }\end{array}$ & $\begin{array}{l}\text { Knitting } \\
\text { yarn }\end{array}$ & $\begin{array}{l}\text { Warp } \\
\text { yarn }\end{array}$ & $\begin{array}{l}\text { Weft } \\
\text { yarn }\end{array}$ & $\begin{array}{c}\text { Knitting } \\
\text { yarn }\end{array}$ \\
\hline \multirow{2}{*}{$\begin{array}{c}\text { Dynamo- } \\
\text { metric } \\
\text { properties }\end{array}$} & $(1,1,1)$ & $(1,1,1)$ & $(1,1,1)$ & $(1 / 2,1,3 / 2)$ & $(1 / 2,1,3 / 2)$ & $(1,1,1)$ & $(3 / 2,2,5 / 2)$ & $(1 / 2,1,3 / 2)$ & $(1,1,1)$ & $(2,1,3 / 2)$ & $(3 / 2,2,5 / 2)$ & $(1,1,1)$ \\
\hline & $(1,1,1)$ & $(1,1,1)$ & $(1,1,1)$ & $(3 / 2,2,5 / 2)$ & $(1,3 / 2,2)$ & $(3 / 2,2,5 / 2)$ & $(1 / 2,1,3 / 2)$ & $(1 / 2,1,3 / 2)$ & $(1,3 / 2,2)$ & $(1,1,1)$ & $(1 / 2,1,3 / 2)$ & $(1,3 / 2,2)$ \\
\hline \multirow{2}{*}{$\begin{array}{c}\text { Neps \& } \\
\text { hairiness }\end{array}$} & & & & $(1,1,1)$ & $(1,1,1)$ & $(1,1,1)$ & $(1,3 / 2,2)$ & $(1,1,1)$ & $(1,1,1)$ & $(3 / 2,2,5 / 2)$ & $(1 / 2,1,3 / 2)$ & $(3 / 2,2,5 / 2)$ \\
\hline & & & & $(1,1,1)$ & $(1,1,1)$ & $(1,1,1)$ & $(1,1,1)$ & $(1,1,1)$ & $(1,1,1)$ & $(3 / 2,2,5 / 2)$ & $(1,1,1)$ & $(1 / 2,1,3 / 2)$ \\
\hline \multirow{2}{*}{$\begin{array}{l}\text { Evenness } \\
\text { properties }\end{array}$} & & & & & & & $(1,1,1)$ & $(1,1,1)$ & $(1,1,1)$ & $(1 / 2,1,3 / 2)$ & $(1 / 2,1,3 / 2)$ & $(3 / 2,2,5 / 2)$ \\
\hline & & & & & & & $(1,1,1)$ & $(1,1,1)$ & $(1,1,1)$ & $(3 / 2,2,5 / 2)$ & $(1 / 2,1,3 / 2)$ & $(2,5 / 2,3)$ \\
\hline \multirow{2}{*}{$\begin{array}{c}\text { Structural } \\
\text { caracteristics }\end{array}$} & & & & & & & & & & $(1,1,1)$ & $(1,1,1)$ & $(1,1,1)$ \\
\hline & & & & & & & & & & $(1,1,1)$ & $(1,1,1)$ & $(1,1,1)$ \\
\hline
\end{tabular}
It is worth noting that the mechanical properties of the yarn affect both mechanical properties of fabric and 


\begin{tabular}{|l|c|c|c|c|c|c|}
\hline \multicolumn{2}{|c|}{ WEIGHT OF THE GLOBAL PROPERTIES WGI FOR THE DIFFERENT YARNS USED } \\
\hline \multirow{2}{*}{ Properties } & Weaving warp yarn & Weaving weft yarn & \multicolumn{2}{c|}{ Knitting yarn } \\
\cline { 2 - 8 } & Weight & Rank & Weight & Rank & Weight & Rank \\
\hline Dynamometric Properties & 0.297 & 1 & 0.270 & 1 & 0.433 & 1 \\
\hline Neps \& hairiness & 0.288 & 2 & 0.152 & 3 & 0.249 & 3 \\
\hline Evenness Properties & 0.221 & 3 & 0.317 & 2 & 0.283 & 2 \\
\hline Structural characteristics & 0.192 & 4 & 0.258 & 4 & 0.033 & 4 \\
\hline Consistency ratio (CR) & \multicolumn{2}{|c|}{0.049} & \multicolumn{2}{c|}{0.065} & \multicolumn{2}{c|}{0.020} \\
\hline
\end{tabular}

yarn breakage during the process of transformation. For example, a yarn with high tenacity leads to a fabric with high tenacity. On the other hand, when the elasticity of the yarn decreases the probability to cause breakage in weaving preparation (for example) increases.

Evenness Properties is the second important criterion for both weaving weft and knitting yarn with a weight of (0.317) and (0.283), respectively.

A defect on yarn affects both yield of production (for example when the number of thin places increases the yield of knitting process decreases) and final declassification of fabric (Fabric with a high rate of defects will be considered as a poor quality product).
All these conclusions are in agreement with previous studies [18-20].

The variation in the weight values can be explained by the difference in the final use of the yarn.

For example, mechanical constraints applied to warp yarns during weaving are more important than that for weft yarns.

Figure 3 presents the relative weight and the ranking of each property studied for the three yarn employments. Since $C R$ is less than 0.1 , the consistency ratio of $\check{A}$ is acceptable $[16,17]$. Results indicate for each yarn the characteristic that spinner or knitter should give the priority to improve the quality and therefore, the customer satisfaction.

\section{Dynamometric properties}

Knitting yarn. $\mathrm{CR}=0.02$

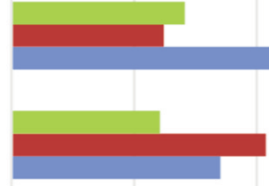

Weaving warp yarn. $C R=0.047$

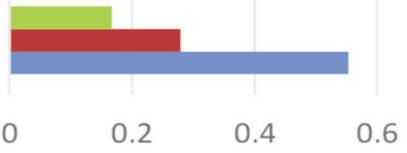

Elasticity Breaking elongation $\quad$ Tenacity

\section{Evenness properties}

Knitting yarn. $\mathrm{CR}=0.018$

Weaving weft yarn.

$\mathrm{CR}=0.014$

Weaving warp yarn. $\mathrm{CR}=0.053$

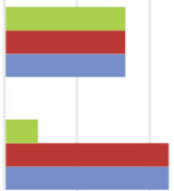

$\begin{array}{llllll}0 & 0.2 & 0.4 & 0.6 & 0.8 & 1\end{array}$

Thick places $\quad$ Thin places CV, \%

\section{Neps \& hairiness}

Knitting yarn. $C R=0.012$

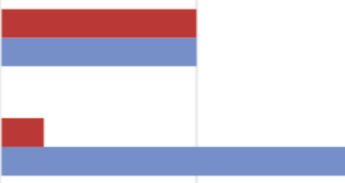

Weaving warp yarn $\mathrm{CR}=0.012$

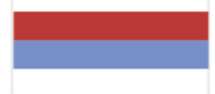

0.5

n Hairiness neps

Structural characteristics

Knitting yarn. $\mathrm{CR}=0.019$

Weaving weft yarn $\mathrm{CR}=0.006$

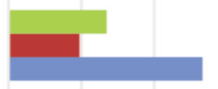

Weaving warp yarn. $\mathrm{CR}=0.021$

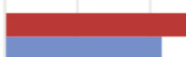

$\begin{array}{llllll}0 & 0.2 & 0.4 & 0.6 & 0.8 & 1\end{array}$

- Twist variation $\quad$ Twist $\quad$ Linear density

Fig. 3. Weights and ranking of sub criteria 


\section{CONCLUSION}

The evaluation of the global quality of the yarn is a multi-criteria problem. In many cases, especially when we make a survey to optimise the properties of yarns, we need a Global Quality Index.

In this paper, we used the 'new approach' Analytic Hierarchy Process AHP and Fuzzy theory to determine a simple Quality Yarn Index QYI taking into account important properties of the yarn and their weights.

This same approach can be used in other textile fields when different properties affect the quality of the final product.

Further studies are necessary to apply the method for a specific application (optimization of the quality of waste yarn for example).

\section{REFERENCES}

[1] Cheng, L., Adams, D.L., Yarn strength prediction using neural networks. Part1: Fiber properties and yarn strength relationship, In: Text. Res. J., 1995, 65, 9, 495-500

[2] Ramesh, Mc., Rajamaniachan, R., Jayaraman, S., The prediction of yarn tensile properties by using artificial neural networks, In: Text.Res. J.,1995, 86, 459-468

[3] Sette, S., Boullart, L., Vangenhove, L., Kiekens, P., Optimizing the fiber-to-yarn production process with a combined neural network / Genetic Algorithm Approach, In: Text. Res, J., 1997, 67, 2, 84-92

[4] Rangaswamy, R., Hassen, M.S., Jayaraman, S., Analysis of the modeling methodologies for predicting the strength of Air-Jet spun yarns, In: Text. Res. J., 1997, 67, 39-44

[5] El Mogahzy, Y., Broughton, Jr.R., Lynch, W.K., A statistical approach for determining the technological value of cotton using HVI fiber properties, In: Text. Res. J., 1990, 59, 495-500

[6] Pan, N., Hua, T., Qiu, Y., Relationship between fiber and yarn strength, In: Text. Res. J., 2001, 71, 960-964

[7] Yunus, M., Rhman, F., Micronaire Effects, In: Text. Asia., 1990, 13, 58-61

[8] Halimi, M.T., Ben Hassen, M., Sakli, F., Effect of cotton waste and spinning parameters on rotor yarn quality, In: Journal of the Textile Institute, 2007, 98, 5, 437-442

[9] Halimi, M.T., Ben Hassen, M., Sakli, F., Influence of spinning parameters and recovered fibers from cotton waste on the uniformity and hairness of rotor spun yarn, In: Journal of Engineered Fibers and Fabrics, 2009, 4, 3, 36-44

[10] Souid, H., Sahnoun, M., Babay, A., Cheikrouhou, M., A Generalized Model for Predicting Yarn Global Quality Index, In: The Open Textile Journal, 2012, 5, 8-13

[11] Wanassi, B., Azzouz, B., Ben Hassen, M., Sustainable Denim Yarn: Quality-Cost Analysis and Analytic Hierarchy Process (AHP) Optimization, In: AATC Journal of Research, 2018, 5, 4, 17-24

[12] Saaty, T.L., Fundamentals of decision making and priority theory with the analytic hierarchy process, Pittsburgh, PA: RWS Publications, 1994

[13] Prakash, C., Barua, M.K., Integration of AHP-TOPSIS method for prioritizing the solutions of reverse logistics adoption to overcome its barriers under fuzzy environment, In: Journal of Manufacturing Systems, 2015, 37, 599-615

[14] Dweiri, F., Kumar, S., Khan, S.A., Jain, V., Designing an integrated AHP based decision support system for supplier selection in automotive industry, In: Expert Systems With Applications, 2016, 62, 273-283

[15] Chan, F.T.S., Kumar, N., Global supplier development considering risk factors using fuzzy extended AHP-based approach, In: Omega, 2007, 35, 4, 417-31

[16] Carnero, M.C., Multicreteria for maintenance benchmarking, In: Journal of manufacturing systems, 2014, 33, 303-321

[17] SeongKon, L., Gento, M., SangKon, L., JongWook, K., Prioritizing the weights of hydrogen energy technologies in the sector of the hydrogen economy by using a fuzzy AHP approach, In: International Journal of Hydrogen Energy 2011, 36, 1897-902

[18] Zulfikar, A.M., Tanveer, H., Mumtaz, H.M., Selection of Yarn for the Predefined Tensile Strength of Cotton Woven Fabrics, In: Fibers and Polymers, 2011, 12, 2, 281-9287

[19] Pelin, U., Mustafa, E., Diren, M., Predicting Properties of Single Jersey Fabrics Using Regression and Artificial Neural Network Models, In: Fibers and Polymers, 2012, 13, 1, 87-95

[20] Levi, A., et al., ISCIS 2006, LNCS 4263, 325-333

Authors:

MOHAMED BEN HASSEN ${ }^{1,2}$, MOHAMED TAHER HALIMI ${ }^{3}$, EMAD ABUALSAUOD ${ }^{1}$, ASEM OTHMAN $^{1}$

${ }^{1}$ College of Engineering, Department of Industrial Engineering, Taibah University, 344 Madina, 41411, Saudi Arabia

${ }^{2}$ Laboratory of Textile Engiunnering, University of Monastir, ISET Ksar Hellal, Hadj Ali Soua, BP 68, Ksar-Hellal 5070, Tunisia

${ }^{3}$ Financial and administrative sciences Department, Community College Dammam Imam Abdulrahman Bin Faisal University, P.O. Box 1982 Dammam, Kingdom of Saudi Arabia e-mail: mthalimi@iau.edu.sa

\section{Corresponding author:}

